\title{
SOX11 wt Allele
}

National Cancer Institute

\section{Source}

National Cancer Institute. SOX11 wt Allele. NCI Thesaurus. Code C105080.

Human SOX11 wild-type allele is located in the vicinity of 2 p25 and is approximately $9 \mathrm{~kb}$ in length. This allele, which encodes transcription factor SOX-11 protein, plays a role in the negative regulation of transcription. 